\title{
ДОСЛІДЖЕННЯ АКТИВНОСТІ ЕНЕРГЕТИЧНИХ ПРОЦЕСІВ У ЩУРІВ ЗА УМОВ ТЮТЮНОВО-НІТРИТНОЇ ІНТОКСИКАЦІЇ ПІСЛЯ ЗАСТОСУВАННЯ КАРБОЛАЙНУ
}

Вступ. Значну роль у розвитку патології відіграють шкідливі звички: тютюнокуріння, зловживання алкологем та медикаментозними засобами. Значною екологічною та медико-біологічною проблемою $\epsilon$ комбінована дія на організм людини і тварин неорганічних нітросполук, що супроводжується випадками нітратно-нітритних інтоксикацій. Унаслідок сумації фракторів ризику навколишнього середовища може виникнути патологічний процес, в якому задіяні всі органи і тканини. Це зумовлює доцільність вивчення механізмів комбінового впливу на організм нітритів і тютюнового диму.

Мета дослідження - вивчити активність процесів енергозабезпечення у щурів за умов тютюново-нітритної інтоксикації та дослідити есрективність застосування при цій патології ентеросорбенту карболайну.

Методи дослідження. Дослідження проведено на білих щурах-самцях, яких поділили на 3 вікові групи: статевонезрілі, статевозрілі й старечого віку. Тютюновий дим, що утворювався від горіння 6 сигарет із вмістом 0,6 мг нікотину та 8 мг смоли, через отвори в герметичній камері подавали всередину неї, де одночасно перебувало 6 тварин упродовж 6 хв. Натрію нітрит щури отримували одноразово інтрагастрально в дозі 45 мг/кг маси тіла. 3 експерименту тварин виводили на 45-ту добу тютюнової інтоксикації (і після 24 та 72 год отруєння натрію нітритом) шляхом евтаназії під тіопенталовим наркозом. У нейтрофрілах крові визначали вміст активних форм оксигену (АФО), у крові - мет- (MetHb) і карбоксигемоглобіну (HbCO), в легенях та серці-сукцинатдегідрогеназну (СДГ) і цитохромоксидазну (ЦО) активність. Усі експерименти проводили відповідно до положень Європейської конвенції про захист хребетних тварин, що використовуються для дослідних та інших наукових цілей.

Результати й обговорення. На 45-ту добу нітритно-тютюнового токсикозу в крові щурів вірогідно підвищувався вміст АФО, MetHb і HbCO. Найбільш виражені зміни спостерігали у крові статевонезрілих тварин. До кінця дослідження СДГ активність у легенях статевонезрілих щурів знизилась у 2,1 раза, статевозрілих - в 1,9 раза, тварин старечого віку - в 1,7 раза щодо рівня контрольних щурів. Найбільш виражені зміни активності цих ензимів відмічено в міокарді щурів старечого віку. Застосування карболайну призвело до вірогідного підвищення СДГ активності в легенях тварин усіх дослідних груп, у міокарді спостерігали тенденцію до зростання даного показника. У статевонезрілих і щурів старечого віку ЦО активність у легенях знизилась на 60 \% після ураження, у статевозрілих - на 50 \%. Міокард щурів старечого віку виявився більш чутливим щодо цього показника. Застосування карболайну призвело до часткового відновлення активності ензимів енергозабезпечення.

Висновки. У крові статевонезрілих щурів за умов нітритно-тютюнового токсикозу відмічено найбільш виражене підвищення вмісту активних фформ оксигену, який знижувався після застосування ентеросорбенту карболайну. Карболайн спричинив вірогідне зменшення вмісту метгемоглобіну в крові тварин усіх вікових груп. При дослідженні вмісту карбоксигемоглобіну після застосування сорбенту спостерігали тенденцію до його зниження. У міокарді та легенях уражених токсикантами щурів відмічено вірогідне зменшення активності енергетичних ензимів, яке достовірним було у статевонезрілих щурів і тварин старечого віку. Застосування карболайну призвело до незначного підвищення сукцинатдегідрогеназної та цитохромоксидазної активності як у легенях, так і в міокарді щурів усіх вікових груп.

КЛЮЧОВІ СЛОВА: натрію нітрит; тютюновий дим; метгемоглобін; карбоксигемоглобін; енергетичні ензими; карболайн.

ВСТУП. На сьогодні одним із найбільш поширених екоантропогенних агентів є тютюновий дим, що має широкий спектр впливу на моророфункціональний стан різних систем організму (с) П. Г. Лихацький, Л. С. Фіра, Д. Б. Фіра, К. О. Алексевич, 2021.
[1]. Згідно з результатами досліджень соціологічного центру Єврокомісії "Євробарометр", встановлено, що середньостатистичний курець в ЄС викурює 14 цигарок на день. При цьому тютюн стає причиною смерті половини курців [2]. 
Небезпека тютюнокуріння полягає у негативному впливі не лише на стан здоров'я курців, але й на самопочуття осіб, які не курять, проте піддаються шкідливому впливу забруднювачів, що надходять в атмосфрерне повітря з тютюновим димом (ТД) [3].

Відомо, що в основі патогенної дії забрудненого полютантами або тютюновим димом повітря лежить оксидантна агресія на слизову оболонку дихальних шляхів активними фрормами оксигену, діоксидами нітрогену та сульсруру, іншими вільними радикалами, що призводить до активації пероксидного окиснення ліпідів і ушкодження біологічних мембран [4].

У повсякденному житті людина піддається впливу декількох токсичних чинників, що призводить до загального отруєння організму.

Забруднення навколишнього середовища хімічними сполуками спричинило виникнення раніше не відомих хронічних захворювань і патологічних станів. Значною екологічною та медико-біологічною проблемою є комбінована дія на організм людини і тварин неорганічних нітросполук, що супроводжується випадками нітратно-нітритних інтоксикацій.

Дія натрію нітриту $(\mathrm{HH})$ полягає перш за все в окисненні оксигемоглобіну до метгемоглобіну (MetHb) та різкому зростанні інтенсивності вільнорадикальних реакцій. Різке збільшення у клітині вмісту проміжних продуктів відновлення кисню позначається на фрункціонуванні дихального ланцюга мітохондрій та організму загалом. Відповіддю на дію зовнішнього чинника (індуктора гіпоксії) $є$ зміна енергетичного обміну в клітині, що суттєво залежить від вихідного стану мітохондрій [5].

Комбінація зазначених впливів нітритів на організм людини та тютюнокуріння дають початок формуванню поєднаних патологічних станів і виникненню поліорганної патології.

Зростання кількості захворювань і патологічних станів, при яких суттєву роль відіграють порушення оксидативних процесів, імунної та запальної відповідей, спричиняє виникнення і поглиблення проявів ендогенної інтоксикації, механізми розвитку якої (ретенційні, обмінні, резорбційні, інсрекційні) добре відомі [6]. Виходом із такої ситуації може бути якомога ширше та водночас обережне використання під час проведення лікувально-просрілактичних заходів ентеросорбентів. Серед значної кількості сорбентів, які на сьогодні застосовують у клінічній практиці, значне місце належить препарату "Карболайн", що і став об'єктом наших досліджень.

Мета дослідження - вивчити активність процесів енергозабезпечення у щурів за умов тю- тюново-нітритної інтоксикації та дослідити есрективність застосування при цій патології ентеросорбенту карболайну.

МЕТОДИ ДОСЛІДЖЕННЯ. Експериментальну частину роботи виконано на базі Центральної науково-дослідної лабораторії Тернопільського національного медичного університету імені І. Я. Горбачевського МОЗ України. Досліди проведено на білих щурах-самцях, яких утримували на стандартному раціоні віварію ТНМУ. Тварин було поділено на 3 вікові групи: статевонезрілі 3 масою тіла 60-80 г (3-місячного віку), статевозрілі 3 масою тіла 180-200 г (12-місячного віку) і старечого віку з масою тіла 300-350 г (18-місячного віку).

Модель залежності від хронічної дії тютюнового диму створювали за допомогою герметичної камери об'ємом 30 л, що дозволило щоденно піддавати тварин дії токсиканта. Тютюновий дим, що утворювався від горіння 6 сигарет "Прима срібна (синя)" із вмістом 0,6 мг нікотину та 8 мг смоли (виробник АТ “Імеріал Табакко Продакшин Україна", ДСТУ ГОСТ 3935:2004), через отвори в камері подавали всередину неї. У камері одночасно перебувало 6 щурів упродовж 6 хв. Тварин контрольної групи також утримували впродовж 6 хв у герметичній камері, але не піддавали дії тютюнового диму [7].

Натрію нітрит тварини отримували одноразово інтрагастрально за допомогою зонда у вигляді водного розчину в дозі 45 мг/кг маси тіла, що становить 1/4 від ЛД 50 [8]. Дослідження проводили через 24 та 72 год після потрапляння в організм цього токсиканта.

Статевонезрілим, статевозрілим щурам і тваринам старечого віку після ураження обома токсикантами інтрагастрально вводили вуглецевий ентеросорбент IV покоління карболайн (ТУ У 24.6-05416946-002-2003) у дозі 400 мг/кг маси тіла, починаючи з 15-ї доби інтоксикації тютюновим димом і щодня до кінця експерименту [9]. Дозу препарату підбирали, виходячи із середньотерапевтичної дози для людей та перерахунку їх на тварин [10].

3 експерименту тварин виводили на 45-ту добу тютюнової інтоксикації (і після 24 та 72 год отруєння натрію нітритом) шляхом евтаназії під тіопенталовим наркозом.

Матеріалом дослідження були гомогенат серця, легень, кров та сироватка крові. Кров забирали із серця тварин, і центрифугували ії при частоті обертання $1100 \mathrm{~g}$ упродовж 30 хв. Відібрані органи (250 мг) використовували для отримання гомогенату за допомогою гомогенізатора магнітного "Silent Crusher S" після попередньої перфузії з 2,5 мл фрізіологічного розчину. 
У нейтрофрілах крові визначали вміст активних фрорм оксигену (АФО) [11], мет- [12] і карбоксигемоглобіну (HbCO) [12], в гомогенатах сукцинатдегідрогеназну (СДГ) [13] та цитохромоксидазну (ЦО) [13] активність.

Утримували тварин та проводили експерименти на них відповідно до положень Європейської конвенції про захист хребетних тварин, що використовуються для дослідних та інших наукових цілей [14].

Обробку статистичних даних виконували за допомогою пакета програмного забезпечення SPSS-22 [15]. Отримані значення мали параметричний розподіл, тому різницю між групами було проаналізовано відповідно до t-критерію Стьюдента і непараметричного критерію Вілкоксона для зв'язаних вибірок. Критерій $\chi^{2}$ використали для оцінки різниці між категоріальними даними. Різниця значень імовірності - $p \geq 0,95$ (рівень значимості р). Розбіжності вважали вірогідними при $p \leq 0,05$.

РЕЗУЛЬТАТИЙ ОБГОВОРЕННЯ. ВіДОМО, ЩО токсична дія нітратів та нітритів полягає в здатності активувати вільнорадикальні процеси окиснення, які призводять до розвитку пухлинних процесів, інгібування синтезу ДНК, порушення фрункції ензимних систем [16]. При тютюнокурінні відбувається генерація активних форм оксигену $\left(\mathrm{O}_{2} \cdot\right.$, $\mathrm{OH}-, \mathrm{H}_{2} \mathrm{O}_{2}$ та ін.), які відіграють важливу роль у багатьох фрізіологічних і біохімічних процесах.

Вивчено вміст АФО у нейтрофрільних гранулоцитах крові щурів різних вікових груп після ураження токсикантами. Результати наведено в таблиці 1.

Вміст АФО у нейтрофрільних гранулоцитах крові статевонезрілих щурів після ураження зростав у 3,3 раза, статевозрілих - у 2 рази, тварин старечого віку - в 2,8 раза.
Отже, найбільш виражені зміни вмісту АФО спостерігали у нейтрофільних гранулоцитах крові статевонезрілих тварин після ураження обома токсикантами, найстійкішими виявились статевозрілі щури, про що свідчив найменший відсоток генерування АФО нейтрофільними гранулоцитами крові тварин саме цієї групи.

Вірогідне зниження вмісту АФО спостерігали у статевонезрілих і статевозрілих щурів після 24 год отруєння натрію нітритом на тлі 45-добової інтоксикації тютюновим димом. У тварин старечого віку в цей термін достовірних змін не зареєстровано, проте до кінця експерименту (45 діб ураження тютюновим димом і 72 год після отруєння натрію нітритом) вміст АФО зменшився на $38 \%(p<0,05)$.

Відомо, що потрапляння в організм натрію нітриту супроводжувалося розвитком гемічної гіпоксії, на що вказувало підвищення вмісту метгемоглобіну у крові щурів після ураження. Процес утворення MetHb в організмі має вільнорадикальний характер.

Дослідження вмісту MetHb у крові щурів, уражених натрію нітритом на тлі тютюнової інтоксикації, показало його збільшення у тварин усіх вікових груп упродовж експерименту. Після ураження обома токсикантами найчутливішими виявилися статевонезрілі щури, в яких цей показник різко зростав і до кінця експерименту був найвищим - у 3,3 раза порівняно з контрольними тваринами (рис. 1).

У цей термін дослідження вміст метгемоглобіну в крові статевозрілих щурів підвищився у 2,7 раза, тварин старечого віку - в 2,6 раза щодо рівня контрольних щурів. Після застосування карболайну вміст MetHb у крові статевонезрілих тварин знизився на 76 \%. Аналогічний вплив на процес метгемоглобіноутворення проявив карболайн у групах статевозрілих щурів і тварин старечого віку.

Таблиця 1 - Вміст активних фрорм оксигену (ум. од.) у нейтрофільних гранулоцитах крові щурів різного віку, уражених натрію нітритом на тлі тютюнової інтоксикації, та після застосування карболайну $(\mathrm{M} \pm \mathrm{m}, \mathrm{n}=6)$

\begin{tabular}{|c|c|c|c|}
\hline \multirow{2}{*}{$\begin{array}{c}\text { Термін дослідження, } \\
\text { доба/година }\end{array}$} & \multicolumn{3}{|c|}{ ГГрупа піддослідних тварин } \\
\hline & $\begin{array}{c}\text { статевонезрілі } \\
\text { щури }\end{array}$ & $\begin{array}{c}\text { статевозрілі } \\
\text { щури }\end{array}$ & $\begin{array}{c}\text { щури } \\
\text { старечого віку }\end{array}$ \\
\hline Контрольні щури & $15,06 \pm 0,71$ & $18,47 \pm 0,22$ & $19,87 \pm 0,86$ \\
\hline 45-та доба ТД+24 год НН & $46,43 \pm 1,86^{*}$ & $35,70 \pm 0,52^{*}$ & $50,93 \pm 0,72^{\star}$ \\
\hline $\begin{array}{l}\text { 45-та доба ТД+24 год НН+ } \\
\text { карболайн }\end{array}$ & $36,55 \pm 3,46^{\#}$ & $28,38 \pm 2,79^{\#}$ & $46,12 \pm 2,85$ \\
\hline 45-та доба ТД+72 год НН & $49,25 \pm 2,45^{*}$ & $36,47 \pm 0,48^{*}$ & $55,94 \pm 0,85^{\star}$ \\
\hline $\begin{array}{l}\text { 45-та доба ТД+72 год НH+ } \\
\text { карболайн }\end{array}$ & $44,44 \pm 3,12$ & $31,35 \pm 2,35$ & $48,27 \pm 3,19^{\#}$ \\
\hline
\end{tabular}

Примітка. Тут, у таблицях 2-4 і на рисунках 1, 2:

1. * - вірогідні зміни між показниками контрольних та уражених токсикантами тварин $(p<0,05)$.

2. \# - вірогідні зміни між показниками уражених щурів і тварин, яким вводили карболайн $(p<0,05)$. 


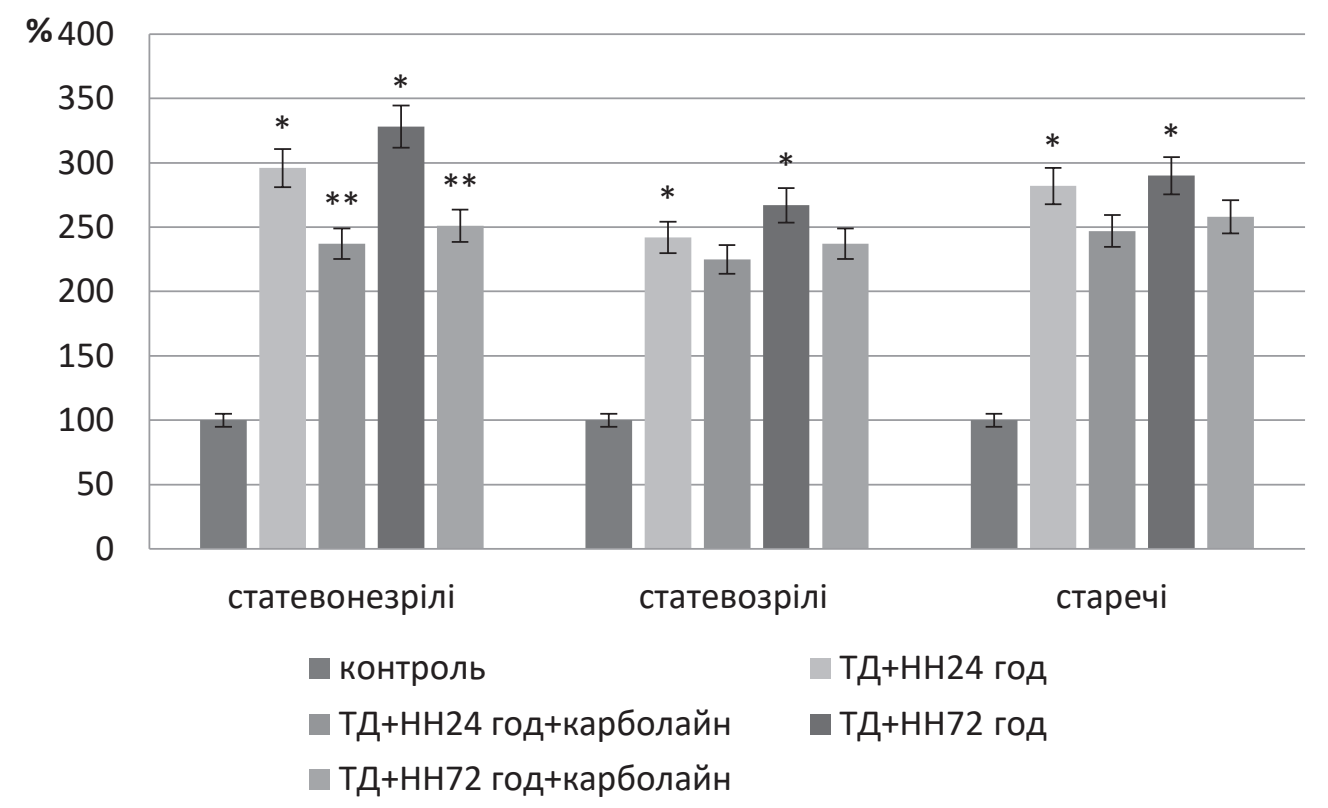

Рис. 1. Вміст метгемоглобіну в крові щурів, уражених натрію нітритом на тлі 45-добової тютюнової інтоксикації, та після застосування карболайну, \%.

Ще одним показником, який характеризує патологічні зміни в організмі тварин після ураження тютюновим димом та сприяє поглибленню гіпоксії, є карбоксигемоглобін. Окис карбону, або чадний газ, що міститься у тютюновому димі, має властивість зв'язувати дихальний пігмент крові - гемоглобін. Утворений при цьому НbCO не здатний переносити кисень; у результаті порушуються процеси тканинного дихання.

Вивчено вміст НbCO у крові токсикованих тютюновим димом щурів різного віку та після ураження їх натрію нітритом, а також при застосуванні ентеросорбента карболайну як коригувального чинника (табл. 2).

При застосуванні карболайну спостерігали тенденцію до зниження вмісту НbCO в уражених щурів, але вірогідних змін не відмічено ні в один термін дослідження у тварин усіх вікових груп.

На даний час малодослідженим залишається питання щодо реакції-відповіді мітохондрій на негативні впливи різної інтенсивності та природи, адже механізм адаптації організму залежить від стану енергетичних процесів у клітині [17]. Мітохондрії відіграють центральну роль у клітинному метаболізмі, забезпечуючи процес клітинного дихання, пов'язаного з генерацією АТФ. Необоротні порушення у структурі та фрункціонуванні мітохондрій, спричинені дією надмірної кількості АФО, зумовлюють зсув енергетичного метаболізму в бік зростання інтенсивності гліколізу і пригнічення окисного фросфрорилювання [18].

Основними маркерними ензимами, що беруть участь у процесах окисного фроссорилювання, $є$ сукцинатдегідрогеназа та цитохромоксидаза, активність яких ми визначали за умов поєднаного впливу натрію нітриту і тютюнового диму на організм.

Встановлено, що за умов одночасного ураження щурів натрію нітритом і тютюновим димом

Таблиця 2 - Вміст карбоксигемоглобіну (г/л) у щурів різного віку, уражених натрію нітритом на тлі тютюнової інтоксикації, та після застосування карболайну (M $\pm m, n=6)$

\begin{tabular}{|c|c|c|c|}
\hline \multirow{2}{*}{$\begin{array}{c}\text { Термін дослідження, } \\
\text { доба/година }\end{array}$} & \multicolumn{3}{|c|}{ ГГрупа піддослідних тварин } \\
\hline & $\begin{array}{c}\text { статевонезрілі } \\
\text { щури }\end{array}$ & $\begin{array}{c}\text { статевозрілі } \\
\text { щури }\end{array}$ & $\begin{array}{c}\text { щури } \\
\text { старечого віку }\end{array}$ \\
\hline Контрольні щури & $0,0148 \pm 0,0012$ & $0,0207 \pm 0,0016$ & $0,0188 \pm 0,0017$ \\
\hline 45-та доба ТД+24 год НН & $0,0428 \pm 0,0040^{*}$ & $0,0328 \pm 0,0028^{*}$ & $0,0408 \pm 0,0026^{*}$ \\
\hline $\begin{array}{l}\text { 45-та доба ТД+24 год НH+ } \\
\text { карболайн }\end{array}$ & $0,0402 \pm 0,0029$ & $0,0293 \pm 0,0025$ & $0,0358 \pm 0,0028$ \\
\hline 45-та доба ТД+72 год НН & $0,0448 \pm 0,0038^{\star}$ & $0,0311 \pm 0,0022^{*}$ & $0,0437 \pm 0,0035^{\star}$ \\
\hline $\begin{array}{l}\text { 45-та доба ТД+72 год НH+ } \\
\text { карболайн }\end{array}$ & $0,0387 \pm 0,0019$ & $0,0273 \pm 0,0022$ & $0,0391 \pm 0,0032$ \\
\hline
\end{tabular}


у тканинах легень та міокарда відмічали зниження показників системи мітохондріального транспорту електронів з максимальним енергодеоріцитом клітин у кінці експерименту.

До кінця дослідження СДГ активність у легенях статевонезрілих щурів знизилась у 2,1 раза, статевозрілих - в 1,9 раза, тварин старечого віку - в 1,7 раза щодо рівня контрольних щурів (табл. 3).

Застосування карболайну призвело до вірогідного $(p<0,05)$ підвищення СДГ активності в легенях тварин усіх дослідних груп.

Чутливим до дії токсикантів був міокард, в якому активність ензиму прогресуюче знижувалась у всі терміни дослідження у статевонезрілих, статевозрілих щурів і тварин старечого віку. Найбільш виражені зміни відмічено в міокарді щурів старечого віку (рис. 2). Після застосування карболайну спостерігали тенденцію до підвищення СДГ активності в цьому органі, проте вірогідних змін не відмічено.

Зниження СДГ активності свідчило про зміни на початкових етапах процесу мітохондріального окиснення, яке супроводжувалося порушенням енергетичного обміну та призводило до формування тканинної гіпоксії. При токсичних уражен- нях (натрію нітритом на тлі хронічної тютюнової інтоксикації) подальше зменшення активності цього ензиму вказувало на прогресування порушень і фрормування тяжких дизенергетичних розладів.

Враховуючи те, що сукцинатдегідрогеназа є інтегральним протеїном внутрішньої мембрани мітохондрій, вона безпосередньо пов'язана 3 ланцюгом перенесення електронів [19]. Зниження її активності може вказувати на зменшення показників АТФ і відновленої фрорми убіхінону, який у мітохондріях відіграє роль безпосереднього акцептора електронів від сукцинатдегідрогенази до III дихального комплексу.

Відомо, що сукцинатдегідрогеназа є одним із ключових регуляторних ензимів циклу трикарбонових кислот, каталізуючи окиснення бурштинової кислоти до фрумарової, а цитохромоксидаза - векторним ензимом внутрішньої мембрани мітохондрій, який регуляє швидкість окисного фоссрорилювання [20]. Вони розташовані, відповідно, на початку та в кінці дихального ланцюга, перебувають в еквімолекулярних взаєминах і організовані в кристах мітохондрії комплексними ансамблями $з$ відповідними проміжками. Дослідження СДГ активності в органах щурів,

Таблиця 3 - Сукцинатдегідрогеназна активність (ммоль/кгхгод) у легенях щурів різного віку, уражених натрію нітритом на тлі тютюнової інтоксикації, та після застосування

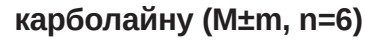

\begin{tabular}{||l|c|c|c||}
\hline \multirow{2}{*}{$\begin{array}{c}\text { Термін дослідження, } \\
\text { доба/година }\end{array}$} & $\begin{array}{c}\text { Гтатевонезрілі } \\
\text { щури }\end{array}$ & $\begin{array}{c}\text { статевозрілі } \\
\text { щури }\end{array}$ & $\begin{array}{c}\text { щури } \\
\text { старечого віку }\end{array}$ \\
\cline { 2 - 4 } & $28,00 \pm 0,73$ & $31,00 \pm 0,86$ & $28,67 \pm 0,67$ \\
\hline Контрольні щури & $14,83 \pm 0,75^{*}$ & $19,83 \pm 0,48^{*}$ & $17,33 \pm 0,80^{*}$ \\
\hline 45-та доба ТД+24 год НН & $18,50 \pm 0,43^{\#}$ & $19,66 \pm 0,65$ & $19,17 \pm 0,31$ \\
\hline $\begin{array}{l}\text { 45-та доба ТД+24 год НH+ } \\
\text { карболайн }\end{array}$ & $13,50 \pm 0,62^{*}$ & $16,50 \pm 0,56^{*}$ & $16,50 \pm 0,34^{*}$ \\
\hline 45-та доба ТД+72 год НН & $17,50 \pm 0,43^{\#}$ & $19,50 \pm 0,96^{\#}$ & $18,67 \pm 0,61^{\#}$ \\
\hline $\begin{array}{l}\text { 45-та доба ТД+72 год НН+ } \\
\text { карболайн }\end{array}$ & & \\
\hline
\end{tabular}

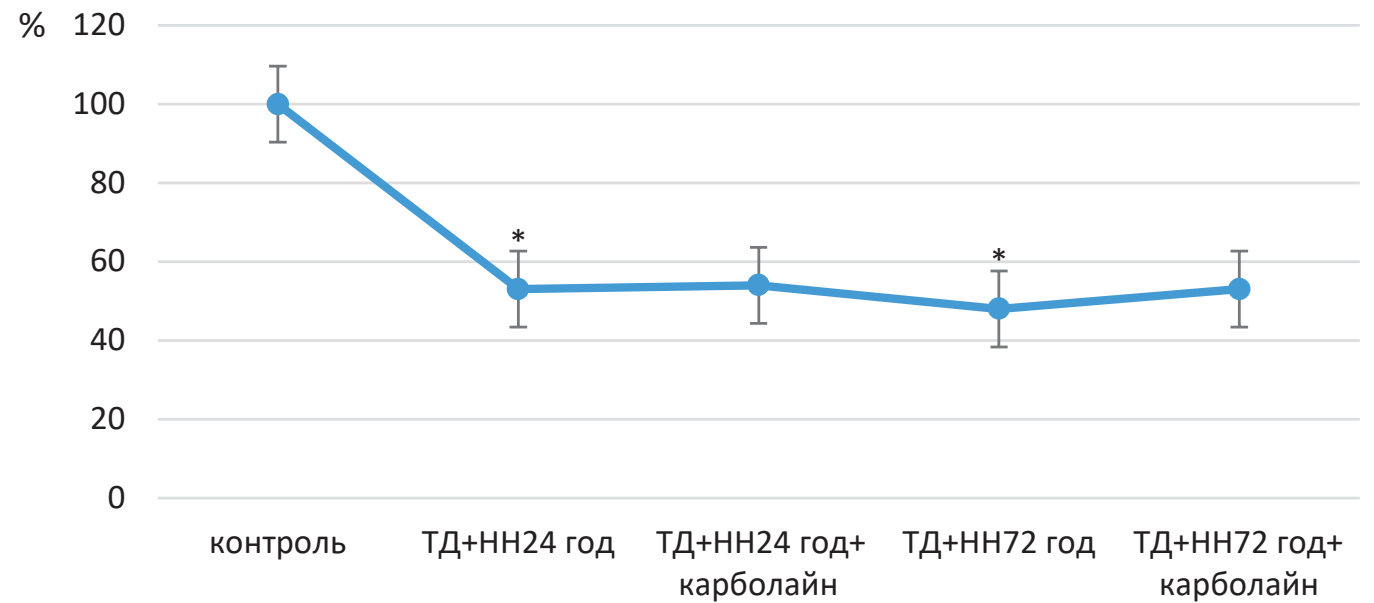

Рис. 2. Сукцинатдегідрогеназна активність у міокарді щурів старечого віку, уражених натрію нітритом на тлі 45-добової тютюнової інтоксикації, та після застосування карболайну, \%. 
отруєних натрію нітритом на тлі тютюнової інтоксикації, та виявлене ії̈ зниження створили передумови для дослідження ЦО активності у тварин різного віку при цьому патологічному стані.

Ураження обома токсикантами призвело до глибокого порушення ЦО активності в легенях тварин. У статевонезрілих щурів і тварин старечого віку цей показник знизився на $60 \%$ у кінці експерименту, в статевозрілих - на 50 \%.

Аналогічне зменшення ЦО активності після ураження спостерігали в міокарді щурів різного віку (табл. 4). Найчутливішим до дії токсикантів виявився міокард тварин старечого віку, в якому активність ензиму до кінця експерименту в 2,2 раза була нижчою від контролю. Застосуван- ня карболайну призвело до вірогідного підвищення цього показника в міокарді щурів усіх вікових груп.

Зниження ЦО активності в мітохондріях клітин різних органів при ураженні токсикантами можна обґрунтувати обмеженням надходження електронів від субстратної ланки дихального ланцюга через цитохроми b-c. Цитохромоксидазна активність може також пригнічуватись через зв'язування вільних кисневих радикалів з атомами металів, які $€$ в складі досліджуваного ензиму.

Отримані зміни активності ензимів свідчать про пригнічення фрункції мітохондрій у легенях та серці щурів, що може бути однією з причин поліорганної недостатності.

Таблиця 4 - Цитохромоксидазна активність (ммоль/кгххв) у міокарді щурів різного віку, уражених натрію нітритом на тлі тютюнової інтоксикації, та після застосування

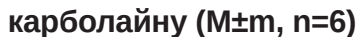

\begin{tabular}{||l|c|c|c||}
\hline \multicolumn{1}{|c|}{$\begin{array}{c}\text { Термін дослідження, } \\
\text { доба/година }\end{array}$} & \multicolumn{3}{|c||}{ Група піддослідних тварин } \\
\cline { 2 - 4 } & $\begin{array}{c}\text { статевонезрілі } \\
\text { щури }\end{array}$ & $\begin{array}{c}\text { статевозрілі } \\
\text { щури }\end{array}$ & $\begin{array}{c}\text { щури } \\
\text { старечого віку }\end{array}$ \\
\hline Контрольні щури & $41,70 \pm 1,55$ & $45,93 \pm 1,79$ & $38,98 \pm 1,30$ \\
\hline 45-та доба ТД+24 год НН & $23,46 \pm 1,18^{*}$ & $25,38 \pm 0,66^{*}$ & $20,85 \pm 0,91^{*}$ \\
\hline $\begin{array}{l}\text { 45-та доба ТД+24 год НН+ } \\
\text { карболайн }\end{array}$ & $30,82 \pm 0,81^{\#}$ & $28,57 \pm 1,21$ & $27,80 \pm 0,76^{\#}$ \\
\hline 45-та доба ТД+72 год НН & $23,27 \pm 0,55^{*}$ & $26,29 \pm 0,91^{*}$ & $17,52 \pm 0,90^{*}$ \\
\hline $\begin{array}{l}\text { 45-та доба ТД+72 год НН+ } \\
\text { карболайн }\end{array}$ & $26,89 \pm 0,56^{\#}$ & $30,82 \pm 0,93^{\#}$ & $26,59 \pm 0,76^{\#}$ \\
\hline \hline
\end{tabular}

ВИСНОВКИ. За умов нітритно-тютюнового токсикозу найбільш виражені зміни вмісту активних фрорм оксигену спостерігали у нейтрофрільних гранулоцитах крові статевонезрілих щурів, найстійкішими виявились статевозрілі тварини. У крові щурів різних вікових груп, отруєних натрію нітритом на тлі тютюнової інтоксикації, вірогідно підвищувався вміст мет- і карбоксигемоглобіну. Найбільш виражені зміни спостерігали у статевонезрілих тварин. Застосування карболайну спричинило достовірне зниження вмісту метгемоглобіну в крові щурів усіх вікових груп. При дослідженні вмісту карбоксигемоглобіну після застосування сорбенту спостерігали тенденцію до його зменшення.

\section{СПИСОК ЛІТЕРАТУРИ}

1. Кваша Е. А. Медицинские аспекты табакокурения / Е.А. Кваша // Здоров'я України. - 2010. № 20 (249). - C. 40-41.

2. Пікас О. Б. Про стан куріння цигарок у сучасних умовах, його вплив на виникнення захворювань в організмі людини / О. Б. Пікас // Буковин. мед. вісн. 2015. - № 6 (4). - С. 227-230.
У міокарді та легенях щурів зареєстровано вірогідне зниження активності енергетичних ензимів, зокрема сукцинатдегідрогенази і цитохромоксидази. Міокард тварин старечого віку виявився найбільш чутливим щодо цих показників.

Отримані дані свідчать про пригнічення фрункції мітохондрій у легенях та серці щурів при нітритно-тютюновому токсикозі, що може бути однією з причин поліорганної недостатності.

Карболайн позитивно вплинув на ці показники, підвищуючи їх у досліджуваних органах. Очевидно, есрект від його застосування опосередкований через зниження проявів ендогенної інтоксикації, що ми зареєстрували раніше.

3. Красовський К. С. Наслідки глобальної тютюнової епідемії / К. С. Красовський // Профрілактична медицина. - 2009. - № 4. - С. 72-74.

4. Cigarette smoke extract affects mitochondrial function in alveolar epithelial cells / K. Ballweg, K. Mutze, M. Königshoff [et al.] // Am. J. Physiol. Lung Cell Mol. Physiol. - 2014. - No. 307 (11). - P. 895-907. 
5. Олійник С. А. Окисний стрес за гіпоксичних станів / С. А. Олійник, О. Л. Козеренко // Вісн. проблем біології і медицини. - 2010. - № 1. - С. 15-21.

6. Evaluation of lipid peroxide and antioxidants in smokers / M. D. Bikkad, S. H. Ghuge, S. D. Somwanshi, S. B. Ingle // Somwanshi International Journal of Basic and Applied Medical Sciences. - 2014. - No. 4 (1). P. 1-6.

7. Churg A. Animal models of cigarette smokeinduced chronic obstructive pulmonary disease /A. Churg, J. Wright// Expert Rev. Respir. Med. -2010. - No. 4 (6). P. 723-734.

8. Смоляр В. І. Нітрати, нітрити та нітрозаміни у харчових продуктах і раціоні / В. І. Смоляр, О. І. Циганенко, Г. І. Петрашенко // Проблеми харчування. 2007. - № 3. - С. 7-8.

9. Андрейчин С. М. Зміни показників цитокінової ланки імунітету у хворих на ХОЗЛ при застосуванні ентеросорбції / С. М. Андрейчин, С. В. Лотоцька, В. М. Мерецький // Інфекційні хвороби. -2015. - № 3. C. 44-47.

10. Рыболовлев Ю. Р. Дозирование веществ для млекопитающих по константе биологической активности / Ю. Р. Рыболовлев, Р. С. Рыболовлев // Журн. AMH CCCP. - 1979. - № 247 (6). - C. 1513-1516.

11. Looney M. R. Neutrophil sandwiches injure / M. R. Looney // Nat. Med. - 2009. - No. 15 (4). - P. 364366.

12. Gladwin M. The new chemical biology of nitrite reactions with hemoglobin: R-state catalysis, oxidative denitrosylation, and nitrite reductase/anhydrase / M. Gladwin, R. Grubina, M. Doyle // Accounts of Chemical Research. - 2009. - No. 42 (1). - P. 157-167.

13. Влізло В. В. Лабораторні методи досліджень у біології, тваринництві та ветеринарній медицині /
В. В. Влізло, Р. С. Федорук, І. Б. Ратич. - Львів : Сполом, 2012. - 764 c.

14. Gross D. Ethics in animal-based research / D. Gross, R. H. Tolba // Eur. Surg. Res. - 2015. No. 55 (1-2). - P. 43-57.

15. Jannot A.S. Citation bias favoring statistically significant studies was present in medical research / A. S. Jannot, T. Agoritsas, A. Gayet-Ageron // J. Clin. Epidemiol. - 2013. - No. 66 (3). - P. 296-301.

16. Ansari F. A. Sodium nitrite enhances generation of reactive oxygen species that decrease antioxidant power and inhibit plasma membrane redox system of human erythrocytes / F. A. Ansari, R. Mahmood // Cell Biol. Int. - 2016. - No. 40 (8). - P. 887-894.

17. Assessment of mitochondrial function following short- and long-term exposure of human bronchial epithelial cells to total particulate matter from a candidate modified-risk tobacco product and reference cigarettes / D. Malinska, J. Szymański, P. Patalas-Krawczyk [et al.] // Food and Chemical Toxicology. - 2018. - No. 115. P. 1-12.

18. Mitochondrial reactive oxygen species and calcium uptake regulate activation of phagocytic NADPH oxidase / S. I. Dikalov, W. Li, A. K. Doughan [et al.] // Am. J. Physiol. Regul. Interg. Comp. Physiol. - 2012. No. 302 (10). - P. 1134-1142.

19. Hypoxia and mitochondrial oxidative metabolism / G. Solaini, A. Baracca, G. Lenaz [et al.] // Biochimica et Biophysica Acta (BBA) - Bioenergetics. - 2010. No. 1797 (6-7). - P. 1171-1177.

20.The role of tobacco smoke induced mitochondrial damage in vascular dysfunction and atherosclerosis / Z. Yang, C. M. Harrison, G. C. Chuang [et al.] // Mutat. Res. - 2007. - No. 621 (1-2). - P. 61-74.

\section{REFERENCES}

1. Kvasha, Ye.A. (2010). Meditsinskiye aspekty tabakokureniya [Medical aspects of tobacco smoking]. Zdorovia Ukrainy - Health of Ukraine, 20 (249), 40-41. [in Ukrainian].

2. Pikas, O.B. (2015). Pro stan kurinnia tsyharok u suchasnykh umovakh, yoho vplyv na vynyknennya zakhvoriuvan v orhanizmi liudyny [On the state of cigarette smoking in modern conditions, its impact on the occurrence of diseases in the human body]. Bukovynskyi medychnyi visnyk - Bukovynian Medical Bulletin, 6 (4), 227-230. [in Ukrainian].

3. Krasovskyy, K.S. (2009). Naslidky hlobalnoi tiutiunovoi epidemii [Consequences of the global tobacco epidemic]. Profilaktychna medytsyna - Preventive Medicine, 4, 72-74 [in Ukrainian].

4. Ballweg, K., Mutze, K., \& Königshoff, M., Eickelberg, O., Meiners, S. (2014). Cigarette smoke extract affects mitochondrial function in alveolar epithelial cells. Am. J. Physiol. Lung Cell Mol. Physiol., 307 (11), 895-907.
5. Oliynyk, S.A., \& Kozerenko, O.L. (2010). Okysnyi stres za hipoksychnykh staniv [Oxidative stress in hypoxic conditions]. Visnyk problem biolohii i medytsyny - Bulletin of Problems of Biology and Medicine, 1, 15-21 [in Ukrainian].

6. Bikkad, M.D., Ghuge, S.H., \& Somwanshi, S.D., \& Ingle, S.B. (2014). Evaluation of Lipid Peroxide and Antioxidants in Smokers. International Journal of Basic and Applied Medical Sciences, 4 (1), 1-6.

7. Churg, A., \& Wright, J. (2010). Animal models of cigarette smoke-induced chronic obstructive pulmonary disease. Expert Rev. Respir. Med., 4 (6), 723-34.

8. Smolyar, V.I., Tsyhanenko, O.I., \& Petrashenko H.I. (2007). Nitraty, nitryty ta nitrozaminy u kharchovykh produktakh i ratsioni [Nitrates, nitrites and nitrosamines in food and diet]. Problemy kharchuvannia - Problems of Nutrition, 3, 7-8 [in Ukrainian].

9. Andreychyn, S.M., Lototska, S.V., \& Meretskyy, V.M. (2015). Zminy pokaznykiv tsytokinovoi lanky imunitetu u khvorykh na KHOZL pry zastosuvanni enterosorbtsii 
[Changes in the indicators of the cytokine level of immunity in patients with COPD with the use of enterosorption]. Infektsiini khvoroby - Infectious Diseases, 3, 44-47 [in Ukrainian].

10. Rybolovlev, Yu.R., \& Rybolovlev, R.S. (1979). Dozirovaniye veshchestv dlya mlekopitayushchikh po konstante biologicheskoy aktivnosti [Dosing of substances for mammals according to the constant of biological activity]. Zhurnal AMN SSSR - Journal of the USSR Academy of Medical Sciences, 247 (6), 1513-1516. [in Russian].

11. Looney, M.R. (2009). Neutrophil sandwiches injure. Nat. Med., 15 (4), 364-366.

12. Gladwin, M., Grubina, R., \& Doyle, M. (2009). The new chemical biology of nitrite reactions with hemoglobin: R-state catalysis, oxidative denitrosylation, and nitrite reductase/anhydrase. Accounts of Chemical Research, 42 (1), 157-167.

13. Vlizlo, V.V., Fedoruk, R.S., \& Ratych I.B. (2012). Laboratorni metody doslidzhen' u biolohiyi, tvarynnytstvi ta veterynarnii medytsyni [Laboratory research methods in biology, animal husbandry and veterinary medicine]. Lviv: Spolom [in Ukrainian].

14. Gross, D., \& Tolba, R.H. (2015). Ethics in animalbased research. Eur. Surg. Res., 55 (1-2), 43-57.

15. Jannot, A.S., Agoritsas, T., \& Gayet-Ageron, A. (2013). Citation bias favoring statistically significant studies was present in medical research. J. Clin. Epidemiol., 66 (3), 296-301.

16. Ansari, F.A., \& Mahmood, R. (2016). Sodium nitrite enhances generation of reactive oxygen species that decrease antioxidant power and inhibit plasma membrane redox system of human erythrocytes. Cell Biol. Int., 40 (8), 887-894.

17. Malinska, D., Szymański, J., \& Patalas-Krawczyk, P., Michalska, B., Wojtala, A., \& Prill, M. (2018). Assessment of mitochondrial function following short- and long-term exposure of human bronchial epithelial cells to total particulate matter from a candidate modified-risk tobacco product and reference cigarettes. Food and Chemical Toxicology, 115, 1-12.

18. Dikalov, S.I., Li, W., \& Doughan, A.K., Blanco, R.R., Zafari, A.M. (2012). Mitochondrial reactive oxygen species and calcium uptake regulate activation of phagocytic NADPH oxidase. Am. J. Physiol. Regul. Interg. Comp. Physiol., 302 (10), 1134-1142.

19. Solaini, G., Baracca, A., \& Lenaz, G., \& Sgarbi, G. (2010). Hypoxia and mitochondrial oxidative metabolism. Biochimica et BiophysicaActa (BBA) - Bioenergetics.,1797 (6-7), 1171-1177.

20. Yang, Z., Harrison, C.M., \& Chuang, G.C., Ballinger, S.W. (2007). The role of tobacco smoke induced mitochondrial damage in vascular dysfunction and atherosclerosis. Mutat Res., 621 (1-2), 61-74.

\section{STUDY OF ENERGY PROCESS ACTIVITY IN RATS UNDER TOBACCO-NITRITE INTOXICATION AFTER CARBOLINE APPLICATION}

\section{Summary}

Introduction. A significant role in the development of pathology is played by bad habits - smoking, abuse of alcohol and drugs. A significant ecological and medico-biological problem is the combined effect of inorganic nitro compounds on the human and animal accompanied by cases of nitrate-nitrite intoxication. A pathological process can arise as a result of the summation of environmental risk factors in which all organs and tissues are involved. This indicates the advisability of studying the mechanisms of the combined action of nitrites and tobacco smoke on the body.

The aim of the study - to analyze the activity of energy supply processes in rats with tobacco-nitrite intoxication and to learn the effectiveness of the use of the enterosorbent carboline in this pathology.

Research Methods. The studies were carried out on male white rats, which were divided into three age groups: immature, mature and old rats. The tobacco smoke generated from the combustion of 6 cigarettes containing $0.6 \mathrm{mg}$ of nicotine and $8 \mathrm{mg}$ of tar through the holes in the sealed chamber was fed into it, where 6 animals were simultaneously kept for 6 minutes. Animals received sodium nitrite once intragastrically at a dose of $45 \mathrm{mg} / \mathrm{kg}$ of body weight. The animals were removed from the experiment on day 45 of tobacco intoxication (and after 24 and 72 hours of sodium nitrite poisoning) by euthanasia under thiopental anesthesia. In blood neutrophils, the content of active forms of oxygen was determined, in the blood - met- and carboxyhemoglobin, in the lungs and heart - succinate dehydrogenase and cytochrome oxidase activity. All experiments were carried out in accordance with the provisions of the European Convention for the Protection of Vertebrate Animals.

Results and Discussion. It was found that on day 45 of nitrite-tobacco toxicosis in the blood of rats, the content of active forms of oxygen, meth- and carboxyhemoglobin probably increased. The most pronounced changes were observed in the blood of immature animals. By the end of the study, succinate dehydrogenase activity in the lungs 
of immature rats decreased 2.1 times, in mature rats -1.9 times, and in old rats -1.7 times relative to the control level. The most pronounced changes in the activity of these enzymes were noted in the myocardium of old rats. The use of carboline led to a likely increase in succinate dehydrogenase activity in the lungs of animals of all research groups, in the myocardium there was a tendency to an increase in this indicator. In immature and old rats, cytochrome oxidase activity in the lungs decreased by $60 \%$ after injury, in mature rats by $50 \%$. The myocardium of old rats turned out to be more sensitive in relation to this indicator. The use of carboline led to a partial resumption of the activity of energy supply enzymes.

Conclusions. In the blood of immature rats under conditions of nitrite-tobacco toxicosis, the most pronounced increase in the content of active forms of oxygen was noted, which decreased after the use of the enterosorbent carboline. Carboline caused a likely decrease in blood methemoglobin in rats of all ages. In the study of the content of carboxyhemoglobin after the application of the sorbent, a tendency to its decrease was observed. In the myocardium and lungs of rats affected by toxicants, a probable decrease in the activity of energy enzymes was noted, which was probable in immature and old animals. The use of carboline led to a slight increase in succinate dehydrogenase and cytochrome oxidase activity both in the lungs and in the myocardium of rats of all ages.

KEY WORDS: sodium nitrite; tobacco smoke; methemoglobin; carboxyhemoglobin; energy enzymes; carboline.

Отримано 10.09.21

Адреса для листування: Л. С. Фіра, Тернопільський національний медичний університет імені І. Я. Горбачевського мОз України, майдан Волі, 1, Тернопіль, 46001, Україна, e-mail: fira@tdmu.edu.ua. 